\title{
Development of conditioned taste aversion to Mascagnia rigida in goats ${ }^{1}$
}

\begin{abstract}
Raquel Ribeiro Barbosa ${ }^{2}$, Idalécio Pacífico da Silva² and Benito Soto-Blanco ${ }^{2 *}$
ABSTRACT.- Barbosa R.R., Pacífico da Silva I. \& Benito Soto-Blanco B. 2008. Development of conditioned taste aversion to Mascagnia rigida in goats. Pesquisa Veterinária Brasileira 28(12):571-574. Programa de Pós-Graduação em Ciência Animal, Universidade Federal Rural do Semi-Árido, BR 110 Km 47, Mossoró, RN 59625-900, Brazil. E-mail: benito.blanco@pq.cnpq.br

The aim of this study was to determine whether goats could be averted from consuming Mascagnia rigida, a toxic plant found in the semiarid region of northeastern Brazil. Fourteen male goats not previously familiarized to $M$. rigida were randomly allocated to two treatment groups: control (treated with $5.5 \mathrm{~mL}$ water orally by a drenching gun) and lithium group (treated with $100 \mathrm{mg} \mathrm{LiCl} / \mathrm{kg}$ body weight orally by a drenching gun). For conditioning, goats were allowed to feed on $M$. rigida leaves for $15 \mathrm{~min}$, followed by $\mathrm{LiCl}$ or water administration. The time spent on eating $M$. rigida leaves was measured. The conditioning was repeated daily until the $\mathrm{LiCl}$-treated goats stopped eating $M$. rigida. On the 10 th, 17th, and 24th day after conditioning, extinction trials of the M. rigida aversion were performed in goats by using single-choice tests. There was no difference between the two treatment groups with respect to the consumption of $M$. rigida on the first day of aversion conditioning, however, controls ingested increasing amounts of the plant on consecutive conditioning days. On the second day, five out of the seven goats in the lithium group did not eat the leaves, but on the third day, all the goats in the lithium group did not ingest $M$. rigida. This aversion persisted throughout all evaluated days. This indicates that goats can be easily conditioned by using lithium chloride to avoid eating $M$. rigida temporarily.
\end{abstract}

INDEX TERMS: Poisonous plants, Mascagnia rigida, Malpighiaceae, conditioned food aversion, taste aversion, diet selection, plant poisoning, goats.

RESUMO.- [Desenvolvimento de condicionamento aversivo ao sabor de Mascagnia rigida em caprinos.] O objetivo do presente estudo foi determinar se os caprinos podem desenvolver aversão ao consumo de Mascagnia rigida, uma planta tóxica encontrada na região semiárida do nordeste brasileiro. Catorze caprinos machos não familiarizados com $M$. rigida foram separados ao acaso em dois grupos de tratamento: controle (tratados com $5,5 \mathrm{~mL}$ de água por via oral por meio de uma seringa dosadora) e grupo tratado lítio (tratados com 100mg de $\mathrm{LiCl} / \mathrm{kg}$ de peso corpóreo por via oral por meio de uma

\footnotetext{
${ }^{1}$ Received on March 28, 2008.

Accepted for publication on June 20, 2008.

2 Programa de Pós-Graduação em Ciência Animal, Universidade Federal Rural do Semi-Árido (UFERSA), BR 110 Km 47, Mossoró, RN 59625-900, Brazil. * Corresponding author: benito.blanco@pq.cnpq.br
}

seringa dosadora). Para o condicionamento, os caprinos puderam ingerir folhas de $M$. rigida por 15 minutos, seguido pela administração de $\mathrm{LiCl}$ ou de água. O tempo de ingestão das folhas de $M$. rigida foi anotado. O condicionamento foi repetido diariamente até que os caprinos tratados com $\mathrm{LiCl}$ parassem de ingerir M. rigida. Nos $10^{\circ}$, $17^{\circ}$ e $24^{\circ}$ dias após o condicionamento, testes de extinção da aversão a $M$. rigida foram realizados nos caprinos usando provas de única escolha. Não houve diferença entre os dois grupos de tratamento no consumo de M. rigida no primeiro dia do condicionamento aversivo, mas os animais do grupo controle ingeriram quantidades crescentes da planta nos dias seguintes ao condicionamento. No segundo dia, cinco dos sete caprinos do grupo tratado com lítio não ingeriram as folhas, mas no terceiro dia, todos os caprinos tratados com lítio não ingeriram $M$. rigida. Esta aversão persistiu durante todos os dias avaliados. Isto 
indica que os caprinos podem ser facilmente condicionados utilizando o cloreto de lítio para produzir aversão à ingestão de $M$. rigida temporariamente.

TERMOS DE INDEXAÇÃO: Plantas tóxicas, Mascagnia rigida, Malpighiaceae, condicionamento aversivo a alimento, aversão ao sabor, seleção da dieta, intoxicação por plantas, caprinos.

\section{INTRODUCTION}

A large number of plant species are known to cause poisoning in animals. In livestock production, toxic plants can cause significant economic losses (James et al. 1992, Riet-Correa \& Medeiros 2001). Mascagnia rigida, from Malpighiaceae family, is the most important poisonous plant in the semiarid region of Brazil, and it causes poisoning, characterized by sudden death in cattle and goats (Tokarnia et al. 1961, Medeiros et al. 2002). This plant is reputed to be palatable, and poisoning is typically acute, with death occurring up to $48 \mathrm{~h}$ after ingestion (Tokarnia et al. 1961, Medeiros et al. 2002) but the toxic compound is not known. Livestock death due to $M$. rigida poisoning is a significant cause of economic loss to local farmers (Medeiros et al. 2002). However, it is not known whether animals could naturally develop avoidance against $M$. rigida.

The best way to reduce economic losses is through prevention of animal poisoning, and conditioned food aversion is a potential management tool for training livestock to avoid eating poisonous plants (Ralphs \& Provenza 1999). Any chemical or physiological state that affects the upper gastrointestinal tract or the emetic center of brain can cause an aversion (Garcia \& Holder 1985). The most used drug for conditioning taste aversions in livestock is lithium chloride, although apomorphine is another common emetic used in large animals (Ralphs \& Provenza 1999). Moreover, lithium chloride has produced better results than apomorphine in creating and maintaining taste aversions in cattle (Ralphs \& Stegelmeier 1998).

The aim of this study was to determine whether lithium chloride-treated goats could be averted from consuming $M$. rigida in the edaphic and climatic conditions of a semiarid region of northeastern Brazil.

\section{MATERIALS AND METHODS}

Fresh Mascagnia rigida leaves were used in this study. They were collected at Mossoró, RN, northeastern Brazil (5¹1'15"S and $\left.37^{\circ} 20^{\prime} 39 " \mathrm{~W}\right)$, at an altitude of $16 \mathrm{~m}$ above sea level. The climate is characterized as semiarid. The mean annual temperature, annual rainfall, and relative humidity are $27.4^{\circ} \mathrm{C}$, $674 \mathrm{~mm}$, and $68.9 \%$, respectively.

Fourteen, 6-month-old to 8-month-old, male goats $(14 \mathrm{~kg} \pm 0.6)$ were used. These animals had not previously been familiarized to $M$. rigida, as most outbreaks of poisoning by this plant in the above region affect naïve animals. Goats were placed in pens of $9.0 \mathrm{~m}^{2}$ with two goats per pen. They were fed with $0.2 \mathrm{~kg} /$ animal/day of concentrate $(0.9 \mathrm{~g} / \mathrm{kg}$ body weight (BW) net energy value); $110 \mathrm{~g} / \mathrm{kg}$ neutral detergent fiber; $21 \mathrm{~g} / \mathrm{kg}$ dry-matter (DM) crude protein; $73 \mathrm{~g} / \mathrm{kg}$ DM PDIA (rumen-undegradable protein truly digestible in the small intestine); $140 \mathrm{~g} / \mathrm{kg}$ PDIN (true protein truly digestible in the small intestine when $\mathrm{N}$ limits microbialprotein synthesis); $120 \mathrm{~g} / \mathrm{kg}$ DM PDIE (true protein truly digestible in the small intestine when energy limits microbial-protein synthesis); $15 \mathrm{~g} / \mathrm{kg} \mathrm{DM} \mathrm{Ca;} 5 \mathrm{~g} / \mathrm{kg} \mathrm{DM} \mathrm{P)}$, and unlimited quantities of Napier grass (Pennisetum purpureum). Water was offered ad libitum.

The goats were randomly allocated to two treatment groups: control group and lithium group. The control group was treated with $5.5 \mathrm{~mL}$ water orally by a drenching gun, and the lithium group received $100 \mathrm{mg} / \mathrm{kg} \mathrm{BW}$ of $\mathrm{LiCl}$ in a $25 \% \mathrm{w} / \mathrm{v}$ solution (a mean volume of $5.5 \mathrm{ml} \mathrm{LiCl}$ solution) by orally by a drenching gun. Tests were conducted in individual pens of $3.0 \times 3.0 \mathrm{~m}$, started daily at 7:30 h. Food was removed from the pens at 18:30 h (13 hours before the beginning of the tests) to exclude interference from any other food or flavor. Furthermore, goats were fasted before ingesting $M$. rigida, and it is feasible that they would ingest any available food.

For conditioning, goats were allowed to feed on $M$. rigida leaves (about $1 \%$ of BW) for $15 \mathrm{~min}$, and at the end of the $15-$ min period, they received a dose of $\mathrm{LiCl}$ (lithium group) or water (control group). The amount of time spent on eating $M$. rigida was measured. There was always some residual quantity of the plant after each trial. Duration of time for which the plant was available and the $\mathrm{LiCl}$ dose were based on a previous study (Ginane \& Dumont 2006). The conditioning was repeated daily until the $\mathrm{LiCl}$-treated goats stopped eating M. rigida.

On the following 10th, 17th, and 24th day after conditioning, extinction trials of the $M$. rigida aversion were performed in goats by using single-choice intake tests. $M$. rigida leaves were offered at about $1 \%$ of $\mathrm{BW}$ for $15 \mathrm{~min}$, and the time spent eating the available plant was measured. $\mathrm{No} \mathrm{LiCl}$ was given to goats in these trials.

Statistical analysis of time spent on eating was carried out using a mixed linear model approach of SAS (SAS Statistical Software V8, 2000, SAS Institute Inc., Cary, NC). Animals were considered as a random factor, with each animal nested within treatments, and with repeated measurements over time. Various mixed models (e.g., compound symmetry, unstructured, and autoregressive) were compared to determine the covariance structure, and the best-fitting model was determined for each dependent variable. Significant day versus treatment interactions were examined using the PDIFF procedure of SAS with preplanned comparisons.

\section{RESULTS}

There were no outward signs of illness or distress caused by plant ingestion or $\mathrm{LiCl}$ treatment in any goat.

On the first day of aversion conditioning, there was no difference between the two groups on consumption of Mascagnia rigida (Fig.1). Furthermore, controls ingested increasing amounts of the plant on successive days, indicating that they readily accepted the plant. No poisoning was observed. On the second day, five out of seven goats from the lithium group abstained from eating the leaves, but the other two still consumed the same (186 s and 194 $\mathrm{s})$, and therefore received a second $\mathrm{LiCl}$ treatment. On the third day, no LiCl-treated goat ingested $M$. rigida. Groups differed on the second and third days in time spent eating the leaves following conditioning $(P<0.001)$ (as shown in Fig. 1). There was also a statistically significant 


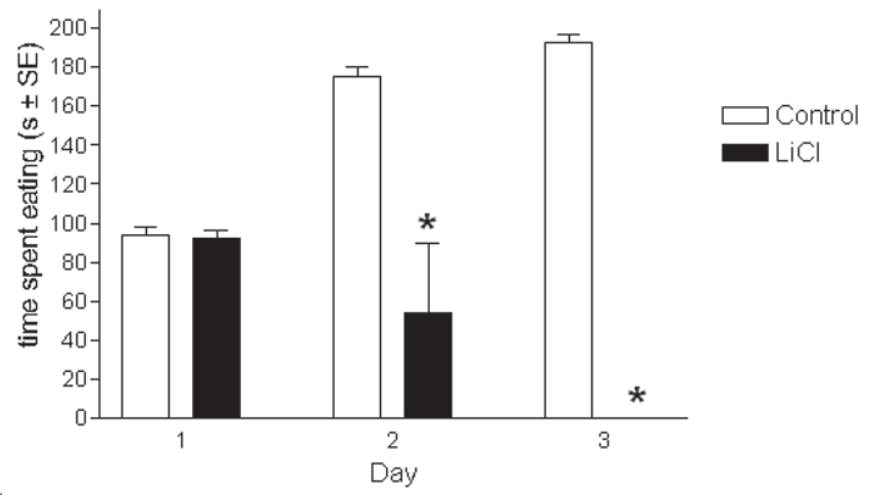

Fig.1. Time spent eating ( $\mathrm{S} \pm \mathrm{SE}$ ) Mascagnia rigida by the control (open bar) and lithium chloride (LiCl)-treated (solid bar) goats $(\mathrm{n}=7$ for each treatment) during aversion conditioning using $\mathrm{LiCl}$ administered at $100 \mathrm{mg} / \mathrm{kg} \mathrm{BW}$ or $5.5 \mathrm{ml}$ water (control) orally by a drenching gun. ${ }^{*} P<0.001$, mixed linear model of SAS.

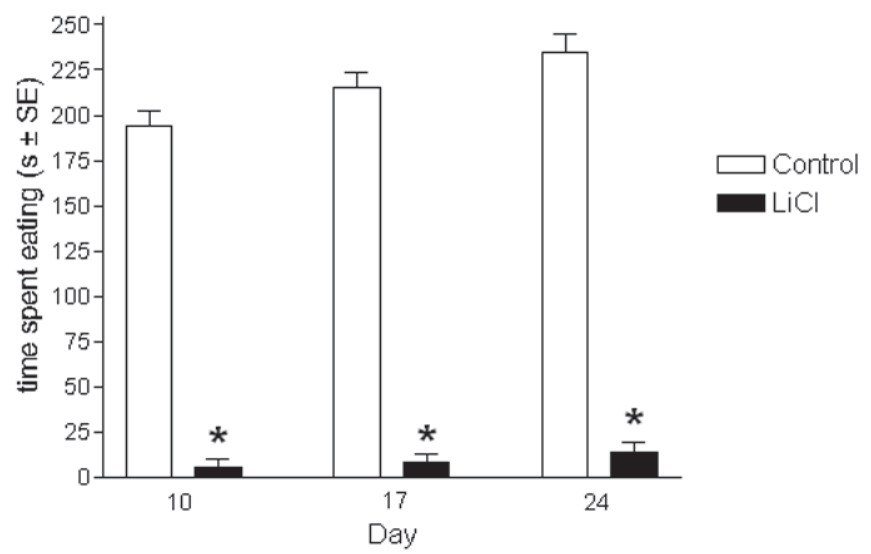

Fig.2. Time spent eating ( $\mathrm{S} \pm \mathrm{SE}$ ) Mascagnia rigida by the control (open bar) and averted (solid bar) goats ( $n=7$ for each treatment) on the following 10th, 17th, and 24th day after conditioning. Goats were averted with $100 \mathrm{mg} / \mathrm{kg} \mathrm{BW}$ lithium chloride ( $\mathrm{LiCl})$; the first day of conditioning was considered day $1 .{ }^{*} P<0.001$, mixed linear model of SAS.

interaction between the day of observation and day versus treatment $(P<0.001)$, indicating that $\mathrm{LiCl}$ dose aversely affects time spent eating $M$. rigida leaves.

Results of the extinction trials of $M$. rigida aversion are presented in Fig. 2. Groups differed on all the evaluated days in time spent eating leaves after conditioning $(P<0.001)$ (as shown in Fig. 2$)$, but no significant differences were found between the groups in the number of days of treatment. Thus, there was no day of treatment versus treatment interaction. This indicates that the aversion to the plant was not extinguished throughout the evaluated days. However, LiCl-treated goats still ate some quantity of the plant.

\section{DISCUSSION}

Aversive taste conditioning might be used for training livestock to avoid the intake of palatable, poisonous plants
(Ralphs \& Provenza 1999, Ralphs 2001). This is particularly important because other ways of control, such as digging up the plant and the use of herbicides, are limited and not effective. Masacagnia rigida is a poisonous plant from the semiarid region of Brazil. Traditional management methods to prevent poisoning, such as limiting the access of animals to the plant and destroying the plant, are not efficient due to the large distribution of the plant throughout several ranges in the region. The results of the present study indicate that goats can be easily conditioned using lithium chloride to avoid eating the poisonous plant $M$. rigida. No poisoning occurred because the amount of plant ingested until then was not enough to cause it.

Recent data are available about the neurobiology of functional alterations of the central nervous system in rewarding and aversive stimuli. Aversive-related stimuli affect nucleus accumbens and prefrontal cortex, which are the same areas involved in reward-related stimuli. In these brain areas norepinephrine transmission is involved in processing the information underlying this behavior through selective increased dopamine release (Jensen et al. 2003, Borsook et al. 2007, Ventura et al. 2007).

Aversions conditioned by lithium chloride are considered strong and last indefinitely if the animals are not compelled to resample the plant (Ralphs 1997). If averted animals ate the target plant without any adverse feedback, they will continue eating it, and eventually the aversion will be extinguished (Ralphs 1997). This can be an important factor interfering with the persistence of the aversion, especially because controls in the present study did not stop ingesting $M$. rigida leaves. However, in the present work, goats were tested for 24 days only, so it is not possible to determine the actual duration of the conditioned aversion. Furthermore, LiCl-treated goats still ate some amounts of the plant. Another factor that affects the persistence of the conditioned taste aversion is the presence of alternative foods for animals (Kimball et al. 2002). However, M. rigida is consumed by animals even when other foods are available (Medeiros et al. 2002).

The persistence of the conditioned taste aversion is also affected by social facilitation, which is considered the greatest impediment to retaining the aversions. As a result of this, conditioned animals may resume eating a poisonous plant to which they were previously averted if they observe other animals eating it. Therefore, averted animals must graze separately from unconditioned animals to maintain the induced aversion (Ralphs \& Provenza 1999).

In conclusion, Mascagnia rigida is the most important toxic plant in the semiarid region of Brazil, and the use of lithium chloride proved effective in creating an aversion to this plant in goats. However, the efficiency of the treatment in the existing conditions of an open range and the persistence of the aversion remain to be evaluated before its practical use by farmers.

Acknowledgments.- This study was funded by "Institutos do Milênio" Program of CNPq (Grant 420012/2005-2). 


\section{REFERENCES}

Borsook D., Becerra L., Carlezon Jr W.A., Shaw M., Renshaw P., Elman I. \& Levine J. 2007. Reward-aversion circuitry in analgesia and pain: implications for psychiatric disorders. Eur. J. Pain. 11:7-20.

Garcia J. \& Holder M.D. 1985. Time, space and value. Human Neurobiol. 4:81-89.

Ginane C. \& Dumont B. 2006. Generalization of conditioned food aversions in grazing sheep and its implications for food categorization. Behav. Proc. 73:178-186.

James L.F., Nielsen D.B. \& Panter K.E. 1992. Impact of poisonous plants on the livestock industry. J. Range Manag. 45:3-8.

Jensen J., McIntosh A.R., Crawley A.P., Mikulis D.J., Remington G. \& Kapur S. 2003. Direct activation of the ventral striatum in anticipation of aversive stimuli. Neuron 40:1251-1257.

Kimball B.A., Provenza F.D. \& Burritt E.A. 2002. Importance of alternative foods on the persistence of flavor aversions: implications for applied flavor avoidance learning. Appl. Anim. Behav. Sci. 76:249-258.

Medeiros R.M.T., Geraldo Neto S.A., Barbosa R.C., Lima E.F. \& RietCorrea F. 2002. Sudden bovine death from Mascagnia rigida in Northeastern Brazil. Vet. Human Toxicol. 44:286-288.
Ralphs M.H. 1997. Long term retention of aversions to tall larkspur in naive and native cattle. J. Range Manag. 50:367-370.

Ralphs M.H. 2001. Plant toxicants and livestock: prevention and management, p.441-470. In: Hui Y.H., Smith R.A. \& Spoerke Jr D.G. (Ed.), Foodborne Disease Handbook. 2nd ed. Marcel Dekker, New York, NY.

Ralphs M.H. \& Stegelmeier B.L. 1998. Ability of apomorphine and lithium chloride to create food aversions in cattle. Appl. Anim. Behav. Sci. 56:129-137.

Ralphs M.H. \& Provenza F.D. 1999. Conditioned food aversions: principles and practices, with special reference to social facilitation. Proc. Nutr. Soc. 58:813-820.

Riet-Correa F. \& Medeiros R.M.T. 2001. Intoxicações por plantas em ruminantes no Brasil e no Uruguai: importância econômica, controle e riscos para a saúde pública. Pesq. Vet. Bras. 21:38-42.

Tokarnia C.H., Döbereiner J. \& Canella C.F.C. 1961. Intoxicação por um "tingui" (Mascagnia rigida Griseb.) em bovinos no Nordeste do Brasil. Arqs Inst. Biol. Animal, Rio de J., 4:203-215.

Ventura R., Morrone C. \& Puglisi-Allegra S. 2007. Prefrontal/accumbal catecholamine system determines motivation salience attribution to both reward- and aversion-related stimuli. PNAS 104:5181-5186. 